\title{
¿ES POSIBLE EL ESTADO DE DERECHO SIN ADHESIÓN AL SISTEMA NORMATIVO?
}

\author{
Jaime CÁRDENAS
}

\section{Resumen:}

La adhesión al sistema normativo es la única forma de conservar el Estado de derecho, el cual se hace posible en la medida en que los ciudadanos sienten la obligación, no sólo jurídica sino también política y moral, de obedecer las normas. Esta obediencia atiende a razones de diversa indole, las cuales son analizadas por el autor a la luz de varias teorias sobre la obediencia, mostrando así los elementos necesarios para la existencia de la obligación de obedecer el derecho.

\section{Abstract:}

Compliance to the normative system is the only way to maintain the Rule of Law, which according to the author becomes possible when citizens feel not only a legal, but also a political and moral obligation to obey the norms. Reasons for obedience are discussed by the author in light of several theories, arriving to a conclusion that states the essential elements for the existence of an obligation to obey the Law. 
JAIME CÁRDENAS

SUMARIO: I. Introducción. II. Algunas posturas sobre la obediencia al derecho. III. Nuestra posición.

\section{INTRODUCCIÓN}

El Estado de derecho sólo será posible si los ciudadanos se sientan obligados —no sólo jurídicamente- a cumplir con las normas. Esa es y será la condición más importante para hablar de Estado de derecho. Sin embargo, el cumplimiento de las normas por parte de los ciudadanos no entraña un acto de fe, sí los ciudadanos respetan las normas de su país es porque además de conocerlas y de tener noción de la importancia de su cumplimiento, saben que esas normas tienen un origen democrático y que están orientadas a salvaguardar sus derechos, que no están diseñadas para el beneficio de los poderosos o de las autoridades. Saben que las autoridades son las primeras en cumplir con las normas y que éstas no tienen un cheque en blanco para hacer lo que les venga en gana, sino que tienen que actuar en consonancia con los preceptos constitucionales y orientando su función al respeto de los derechos humanos, de otra manera cualquier exigencia a los ciudadanos de cumplimiento al sistema normativo carece de sentido. En la filosofia politica y jurídica desde antiguo ha interesado este debate; hace ya algunas décadas, el profesor Hart se refirió al punto de vista interno sobre el derecho, aquél que impacta en el juez y en la autoridad, y que permite que los servidores públicos se sientan identificados con las normas, y comprometidos con su respeto y obediencia. ${ }^{1}$ De lo que se trataría ahora es extender esa adhesión normativa e institucional a los ciudadanos. ¿Cómo hacer que ocurra?

El tema de la obediencia al derecho está ligado con el de la obligación política y, por supuesto, con el de legitimidad de los sistemas políticos y jurídicos. El problema de la obligación política radica en las preguntas: ¿por qué debo obe-

1 Hart, H. L A., El concepto de derecho, traducción de Genaro R. Carrió, México, Editora Nacional, 1980, p. 110. 
decer al Estado?, ¿por qué debo obedecer al derecho? La primera pregunta entraña la legitimidad o justificación del Estado, y la segunda, intimamente relacionada, nos conduce a la cuestión de la fundamentación de las normas jurídicas, de si debemos siempre obedecerlas, y cuáles son las razones para esa obediencia o desobediencia. La respuesta a esta última pregunta es decisiva para contestar a la primera. Generalmente se aducen tres tipos de razones para obedecer al derecho: razones legales, prudenciales y morales. ${ }^{2}$ Las razones legales son tautológicas, en cuanto que se aduce que desde que existe una norma jurídica el ciudadano está obligada a obedecerla. Existe por tanto una identificación entre obligación jurídica y obligación legal. Hans Kelsen al respecto señaló: "La pregunta que se plantea es porqué estas personas deben obedecer al derecho. No nos preguntamos si el derecho positivo es válido, ya que de hecho la teoría del derecho positivo presupone que lo es y ello constituye un rasgo esencial del derecho positivo". ${ }^{3}$ Las razones legales se agotan en el sistema legal, se genera un problema semejante al de la concepción de la legitimidad de la teoría positivista que reduce la legitimidad al orden jurídico sin importar sus contenidos. Las razones para obedecer al derecho deben buscarse fuera del sistema jurídico. ${ }^{4}$ Por su parte, las razones prudenciales para obedecer el derecho se fundamentan en un cálculo, individual o colectivo, entre ventajas y desventajas, entre los incentivos y los costos que supone la infracción a las normas. Estas razones

2 Algunos como Hart y Raz señalan razones sociales que obligan a obedecer el derecho. Raz, Joseph, La ética en el ámbito público, Barcelona, Gedisa, 2001, pp. 227-257. Para el debate sobre las conexiones entre moral y derecho desde una perspectiva positivista véase: Escudero Alday, Rafael, Los calificativos del positivismo jurídico. El debate sobre la incorporación de la moral, Madrid, Civitas, 2004.

3 Kelsen, Hans, “¿Por qué obedecer al derecho?”, ¿Qué es la justicia?, traducción castellana con estudio preliminar de Albert Calsamiglia, Barcelona, Ariel, 1982, p. 183.

4 Esto es, se requiere integrar teorias hétero-poyéticas, que no sean autorreferenciales. Basar la obediencia del derecho, por ejemplo, en los fines valiosos que éste persigue, tal como la realización de los derechos humanos, o la consecución de la igualdad o la libertad. Ferrajoli, Luigi, Derecho y razón. Teoría del garantismo penal, Madrid, Trotta, 1997, pp. 880 y ss. 
son socorridas en toda las teorías económicas del derecho y de la democracia. Ejemplos de razones prudenciales para obedecer al derecho están el temor al castigo o las recompensas que se reciben al tener conductas virtuosas en el sentido establecido por las reglas. Si bien son externas al orden jurídico son insuficientes para reclamar una obediencia de la ley en un sentido fuerte, por lo que podemos llamarlas razones psicosociales porque toman en cuenta factores y elementos que descansan en el estudio de la conducta individual y colectiva, ${ }^{5}$ en los ámbitos personal y social, son razones "interesadas". En cuanto a las razones morales diremos que son aquéllas que se sostienen en contenidos, son razones sustanciales que por ejemplo expresan que se debe obedecer el derecho porque es justo, porque emana de un procedimiento democrático, porque protege los derechos humanos, etcétera. Si se adoptan razones morales para obedecer el derecho se reconoce que existen importantes influencias de la moral al derecho que se deben tomar en cuenta para que éste tenga la pretensión de ser legítimo o justo, ${ }^{6}$ es decir, se dice que el derecho como obra humana debe ganarse la obligación de ser obedecido por la justeza de sus normas.

El problema de la obediencia al derecho tiene una liga con la obligación política, por eso, una vez establecidos los tres tipos de razones que existen para obedecerlo, nos parece que se deben también exponer las diferentes especies de obligación para relacionar a las razones morales con la obligación política. Geoffrey Marshall alude a tres especies de

5 Vergara Lacalle, Óscar, El derecho como fenómeno psicosocial. Un estudio sobre el pensamiento de K. Olivecrona, Granada, Comares, 2004, pp. 250 y ss.

6 Es abundante la bibliografia a favor y en contra de esas relaciones. Véase: Coleman, J., "Negative and Positive Positivism", en Cohen, M. (ed.), Ronald Dworkin and Contemporary Jurisprudence, Londres, Duckworth, 1984, pp. 28-48; Calsamiglia, Albert, "Postpositivismo", Doxa, vol. 21-I, 1998, pp. 209-220; Prieto Sanchís, Luis, Positivismo y constitucionalismo, México, Fontamara, 1997; Raz, Joseph, The Authority of Law. Essays on Law and Morality, Oxford, Clarendon Press, 1979, traducción castellana de Tamayo, Rolando, La autoridad del derecho, México, UNAM, 1985; Dworkin, Ronald, El imperio de la justicia, Gedisa, Barcelona, 1988; Waluchow, W., Inclusive Legal Positivism, Oxford, Clarendon Press, 1994, entre otros muchos. 
¿ES POSIBLE EL ESTADO DE DERECHO...

obligación jurídica: jurídica, moral y política. La obligación jurídica se corresponde con las razones legales ya mencionadas. La obligación moral se origina en la conciencia moral autónoma, voluntaria y libre del individuo, es una obligación "no interesada", impuesta por el respeto al deber y que va más allá de las fronteras de la obligación legal. Este tipo de obligación se identifica con las razones morales. La obligación política perfecciona a la obligación moral individual, pues se apoya en razones morales pero conectadas intimamente con el sistema político. La obligación política presupone la vida en sociedad, la convivencia política, la necesidad de una autoridad. La obligación politica es la suma de las obligaciones legales y morales, en donde las últimas cuestionan a las exclusivamente legales. ${ }^{7}$

La obligación política atiende a las llamadas paradojas de la autoridad para disolverlas. Dice Raz que:

Las paradojas de la autoridad pueden adoptar diferentes formas, pero todas ellas se refieren a la alegada incompatibilidad de la autoridad con la razón y con la autonomía moral. Estar sometido a la autoridad, se argumenta, es incompatible con la razón, puesto que ésta exige que siempre se actúe en base a la balanza de razones de las que uno está consciente. Es de la naturaleza de la autoridad requerir su misión aún cuando se piense que lo que nos es requerido es contrario a la razón, por lo tanto, el sometimiento a la autoridad es irracional. Similarmente el principio de autonomía implica que se actúe en base al propio juicio en todas las cuestiones morales. Como la autoridad algunas veces requiere que se actúe en contra del propio juicio, exige, así el abandono de la autonomía moral. Como todas las cuestiones prácticas pueden implicar consideraciones morales, toda autoridad práctica niega la autonomía moral y es, consecuentemente, inmoral. ${ }^{8}$

7 Marshall, Geoffrey, Teoría constitucional, Madrid, Espasa-Calpe, 1982, pp. 251 y ss.

8 Raz, Joseph, La autoridad del derecho, cit., nota 6, pp. 17 y 18. 
Desde nuestro punto de vista estas paradojas son sólo aparentes como el mismo Raz reconoce, y quedan desvirtuadas cuando se sostiene que es absurdo afirmar que la relación individuo - autonomía moral- y autoridad es incompatible, puesto que si esgrimimos la tesis de que la autoridad sólo es legítima y sólo es autoridad si actúa justamente, entonces no tiene sentido hablar de tales paradojas porque hemos trascendido el formalismo y el positivismo. La autoridad de jure puede y debe ser cuestionada, no se diga la autoridad de facto. La autoridad del derecho para que sea legitima, y el derecho tenga la pretensión de ser obedecido, al menos prima facie, requiere estar basado en razones morales. Eusebio Fernández dice:

El derecho tiene autoridad legitima cuando cuenta con la autoridad moral que le otorga el ser un derecho justo y lo es suficientemente en el caso de que se cumpla con los dos requisitos combinados de haber sido producido democráticamente según el principio de legitimidad contractual y si respeta y garantiza los derechos fundamentales del hombre. ${ }^{9}$

El enfoque que sostiene el carácter finalista y externo para justificar la adhesión al sistema normativo se puede

9 Fernández, Eusebio, La obediencia al derecho, Madrid, Civitas, 1987, pp. 56 y 57. Martínez Yañez, distingue tres tipos de obligaciones: institucional, politica y moral. La obligación institucional de obediencia al derecho está determinada por la propia dinámica del derecho como institución, esta obligación permitiría una justificación intrasistémica del fenómeno de la obediencia, al mismo tiempo que proporcionaria las pistas esenciales sobre las exigencias del deber jurídico, stricto sen$s u$. La obligación política sitúa el fenómeno de la obediencia en el contexto de la sociedad política y dentro de esta noción es necesario distinguir entre dos posibles acepciones, por un lado, la obligación política que no se refiere a ningún sistema político en particular y que se limita a describir la necesidad existencial y vital de cohesión que se encuentra en la base de todo grupo social politicamente organizado, de forma más o menos rudimentario, y por otro lado, la obligación política que evoca un concepto de obligación mucho más depurado, generalmente identificado con una suerte de obligación moral, y cuyo objeto de análisis es una determinada sociedad con un sistema político concreto que es precisamente el sistema democrático. La obligación moral en donde se trata de profundizar en la relevancia moral del derecho como factor de cohesión social, como instrumento de coordinación de conductas, como garante de un cierto orden y de una cierta seguridad jurídica, para concluir que éstos y otros elementos permiten sostener la existencia de una obligación moral de obediencia al derecho. 
¿ES POSIBLE EL ESTADO DE DERECHO...

apoyar en razones políticas democráticas, la defensa de los derechos humanos, o razones morales como la que manifiesta apoyo al sistema jurídico, aunque sea prima facie y a posteriori, cuando éste promueve valores como el de la justicia, la igualdad o la libertad. Esto tiene sentido sólo en las sociedades democráticas que permiten la más amplia libertad de expresión, de manifestación, de resistencia y crítica permanente al sistema normativo y politico. La obligación politica en estas sociedades ${ }^{10}$ no es el resultado de la fuerza ni de la imposición, sino que en todo caso es una respuesta de los ciudadanos, siempre condicionada a los procedimientos y resultados, al poder basado en el consenso, en el disenso y siempre en la tolerancia. ${ }^{11}$ Es decir, en una autoridad o en un sistema jurídico que satisfaga la tres dimensiones a las que alude Marshall: autoridad legitima de origen, de ejercicio y, además, autoridad que acepte que los gobernados no están obligados a prestar obediencias a priori y en todos los casos ilimitadamente, sino cuando la autoridad y el sistema jurídico, son legitimos de origen, en el ejercicio, y permiten el disenso y la crítica a sus dictados. ${ }^{12}$

\section{Algunas posturas SOBRE LA OBEDIEnCiA AL DERECHO}

\section{La posición de John Rawls}

Rawls ${ }^{13}$ sostiene que existe una obligación moral de obedecer las leyes justas, pero igual que ciertos autores como Herbert Hart, Joel Feinberg, Harry Beran o Rex Martin, dis-

10 Martínez Yañez, Nora María, La obediencia al derecho en la España democrática, Madrid, Dykinson, 2000, p. 338.

11 Passerin D’Entreves, "Legitimidad y resistencia", Revista Sistema, Madrid, núm. 13, 1976, p. 27.

12 Marshall, Geoffrey, Teoría constitucional, Madrid, Espasa-Calpe, 1982, pp. 265 y ss.

13 Para este tema no sólo véase $A$ Theory of Justice, también atender a Rawls, John, Political Liberalism, Nueva York, Columbia University Press, 1993. 
tingue entre "deber" y "obligación". ${ }^{14}$ En términos generales para que exista una obligación se precisa la realización previa, voluntaria y consciente de un acto que es condición de la misma. Las obligaciones hacen que una acción que era moralmente neutral pierda prima facie su opcionalidad, a la vez que engendran, derechos correlativos. Los deberes, en cambio, pueden ser neutrales, posicionales o de obediencia, no se adquieren voluntariamente, ni se asumen con abstracción de su contenido, su función es la de prescribir, enseñar, indicar o aconsejar cuál es la conducta correcta teniendo en cuenta todos los factores relevantes que rodean al caso. Rawls considera que las obligaciones son exigencias derivadas del principio de imparcialidad. Según su Teoría de la justicia, a una persona se le puede reclamar que cumpla con el papel definido por las reglas de una institución si satisfacen dos condiciones: que la institución realice los dos principios de justicia, ${ }^{15}$ y que la persona acepte voluntariamente los beneficios del acuerdo o que obtenga provecho de las oportunidades que éste ofrece para promover sus propios intereses. Las obligaciones son por tanto consensuales, y sus vínculos presuponen instituciones justas. Para Rawls, los deberes naturales existen con independencia del consentimiento de las personas (el deber de ayudar a otro cuando lo necesita, el deber de no dañar, etcétera) y no tienen conexión con las instituciones o prácticas sociales, ni su contenido está reglamentado por las reglas de los

14 Malem Seña, Jorge, Concepto y justificación de la desobediencia civil, Barcelona, Ariel, 1988, pp. 18 y ss.; Falcón Tella, María José, La desobediencia civil, Madrid-Barcelona, Marcial Pons, 2000; Urgartemendia Eceizabarrena, Juan Ignacio, La desobediencia civil en el Estado constitucional democrático, Madrid, Marcial Pons, 1999, y Martínez Yañez, Nora María, La obediencia al derecho en la España democrática, cit., nota 10.

15 El primer principio señala que cada persona ha de tener un derecho igual al más amplio sistema total de libertades básicas, compatible con un sistema similar de libertad para todos. El segundo principio señala que las desigualdades económicas y sociales han de ser estructuradas de manera que sean para: a) mayor beneficio de los menos aventajados, de acuerdo con un principio de ahorro justo, y b) unido a que los cargos y las funciones sean asequibles a todos, bajo condiciones de justa igualdad de oportunidades. Rawls, John, Teoría de la justicia, México, Fondo de Cultura Económica, 1985, pp. 340 y 341. 
¿ES POSIBLE EL ESTADO DE DERECHO...

acuerdos. Los deberes surgen de la consideración a la dignidad de las personas como moralmente iguales.

Nuestro autor indica que el deber natural más importante es el de defender y fomentar las instituciones justas. ${ }^{16}$ Este deber tiene dos partes: primera, la de obedecer y cumplir nuestro cometido en las instituciones justas cuando éstas existan y se nos apliquen, y la segunda, hemos de facilitar el establecimiento de acuerdos justos cuando éstos no existan, al menos cuando pueda hacerse un poco de sacrificio de nuestra parte. Por tanto, señala Rawls, si la estructura de la sociedad es justa o todo lo justa que cabe esperar, todos tenemos el deber natural de hacer lo que nos exigen las instituciones.

De conformidad con la distinción entre deber y obligación, Rawls aprecia que las obligaciones se derivan del principio de imparcialidad, ${ }^{17}$ según el cual una persona está obligada a cumplir su parte como lo establecen las normas de una institución cuando ha aceptado voluntariamente los beneficios del esquema institucional, o se ha beneficiado de las oportunidades que ofrece para fomentar sus intereses. De acuerdo con este razonamiento, el principio de imparcialidad obliga sólo a aquellos que asumen un puesto político o están mejor situados. Esto es, los privilegiados adquieren más obligaciones que los que no lo son, con lo cual no es posible, en la posición rawlsiana, hablar de una obligación política para todos los ciudadanos. Lo anterior nos lleva a concluir que Rawls considera que existe un deber natural de obedecer el derecho justo pero no una obligación para hacerlo. Aunque, si admitimos que Rawls acepta como requisito del derecho justo su legitimidad contractual, y esta legitimidad presupone acuerdos voluntarios y ventajosos para todos, entonces es dable opinar que si existe en el pensamiento rawlsiano la obligación moral de obedecer el derecho justo.

16 Ibidem, p. 374.

17 Ibidem, p. 383. 
Rawls, sin embargo, sostiene que existe el deber de obedecer leyes injustas. Manifiesta que "la injusticia de una ley, no es, por lo general, una razón suficiente para no cumplirla, como tampoco la validez legal de la legislación es una razón suficiente para aceptarla".18 Afirma que cuando la estructura básica de la sociedad es razonablemente justa hemos de reconocer que las leyes injustas son obligatorias siempre que no excedan ciertos limites de injusticia. Entre los razonamientos adicionales que proporciona para defender su posición está el que se apoya en el deber de urbanidad que:

...impone la aceptación de los defectos de las instituciones, y ciertos límites para poder beneficiarnos de estos defectos. Sin el reconocimiento de este deber la fe y la confianza mutua están expuestas a desaparecer. Por tanto, en un estado próximo a la justicia, existe normalmente el deber (y para algunos también la obligación) de obedecer las leyes injustas. 19

No podemos compartir la visión rawlsiana en este punto. En un Estado democrático "casi justo", es importante seguir mejorando los niveles de justicia, a través de los correctivos institucionales que provee el Estado de derecho pero también por medio de instrumentos como el de la resistencia y la desobediencia civil que se realizan por medios pacíficos y no violentos. ${ }^{20}$ La obediencia a un sistema jurídico es siempre prima facie, sujeta a la manera en que se desarrollan los procedimientos democráticos y las características y condiciones de los resultados que arrojan esos procedimientos. También debemos señalar que la teoría de Rawls es débil respecto a sus aspectos deliberativos, pues el conocimiento moral, aún en la posición originaria, es fundamentalmente individual. Rawls no prestó suficiente

18 Ibidem, p. 392.

19 Ibidem, p. 396.

20 Rawls, John, "La justificación de la desobediencia civil", Justicia como equidad. Materiales para una teoría de la justicia, Madrid, Tecnos, 1986, pp. 90-101. 
¿ES POSIBLE EL ESTADO DE DERECHO...

interés al consenso deliberativo para alcanzar decisiones morales debidamente justificadas. ${ }^{21}$

\section{La tesis de Ronald Dworkin ${ }^{22}$}

Para comprender la teoría de Dworkin sobre la obediencia al derecho, debemos tener en cuenta que el derecho y el Estado, en su obra, no son otra cosa que instrumentos de garantía de los derechos individuales, esto es, la idea de que la organización jurídica debe estar orientada sólo a tutelar los derechos que se presentan como derechos humanos, caracterizados como básicos y naturales. De esta premisa básica y fuerte sobre los derechos, entiende que el deber general de obediencia o el deber social de lealtad al derecho, no se repite sin más de la doctrina tradicional sobre la obligación política. ${ }^{23}$ Considera que sólo cuando el derecho es producto de un Estado democrático, y es fruto también del respeto a los derechos individuales, básicamente a la dignidad y a la igualdad, podemos hablar de un deber moral de obediencia. El deber se caracteriza por ser individual, en conciencia: por eso señala que la conducta del ciudadano no es injusta mientras se guie por su propia opinión, considerada y razonable, de lo que exige la ley, ${ }^{24} \mathrm{y}$ ello por la peculiaridad del sistema constitucional de los Estados Unidos que, según Dworkin, reside en el hecho de remitir la cuestión de la obediencia concreta a la decisión individual. Es cada ciudadano quien debe decidir, contras-

21 Rawls, John, "The Idea of Public Reason", Political Liberalism, Nueva York, Columbia University Press, 1993.

22 No debe perderse de vista que la teoria de Dworkin es en gran parte una respuesta a las tres tesis "positivistas" de la teoria de Hart: la tesis de la separación conceptual entre derecho y moral, la tesis de las fuentes sociales del derecho y la tesis de la discrecionalidad judicial. Para conocer la respuesta de Hart a Dworkin véasee: Hart, H. L. A., Post-scriptum al concepto de derecho, traducción y estudio preliminar de Rolando Tamayo y Salmorán, México, UNAM, Instituto de Investigaciones Jurídicas, 2000.

23 Dworkin, Ronald, Los derechos en serio, Barcelona, Ariel, 1984, pp. 279 y 315 .

24 Ibidem, p. 318. 
tando los argumentos que apoyan o no la obediencia, lo que exige en última instancia que exista un mínimo de consenso social sobre los criterios de la conducta. El individualismo en este sentido no es arbitrario. Dworkin expresa que para que la opinión individual sea considerada y razonable, no podrá dejar de examinarse el precedente judicial, y ello no porque sea por fuerza el procedimiento correcto para la decisión justa, sino porque se trata de lo coherente con la peculiaridad del sistema jurídico en cuestión. Es decir, para sostener el modelo de reconstrucción racional en lo referente al razonamiento jurídico, que es otra de las tesis centrales de Dworkin, es necesario confrontar, utilizar los elementos que nos proporciona el derecho: normas, reglas, principios y resoluciones judiciales: quien rechace sin más o no argumente de modo suficiente el por qué de su rechazo al precedente, no podrá tener a su favor, por ejemplo, la presunción de que la propia opinión es considerada y razonable. ${ }^{25}$ Lo anterior lleva a la conclusión de que, si persiste la duda, debe seguirse el propio juicio, deben prevalecer los derechos, o, en otras palabras, que el criterio último es la prioridad de los derechos morales porque así lo exige la tesis de los derechos "fuertes".

La teoría de Dworkin no deja dudas sobre la existencia de un deber moral de obedecer el derecho cuando éste es el resultado de un procedimiento democrático y del respeto a los derechos humanos. Dworkin sostendrá que cuando las normas del derecho positivo no son satisfactorias o cuando éstas son insuficientes, siempre existe el recurso a "bucear" en la totalidad del derecho para encontrar la única solución correcta, de hecho a través de los principios que forman parte de la realidad jurídica, aunque sean principios morales, se puede identificar el contenido del derecho para el caso concreto, por lo que la tesis de la separación conceptual entre la realidad normativa del derecho y de la moral 
¿ES POSIBLE EL ESTADO DE DERECHO...

es falsa. ${ }^{26} \mathrm{El}$ individuo tiene un derecho a la desobediencia cuando la autoridad desconoce un derecho fundamental, aunque esa desobediencia no puede practicarse por cualquier medio, debe implicar un razonamiento sobre las normas del derecho en cuestión y verificarse por vias pacíficas.

\section{La teoría del consentimiento}

Se trata de una teoría compleja que puede revestir en algunos casos y en ciertos autores el tono de las teorias neocontractualistas - Rawls, Nozick, Buchanan-. Por eso, algunos como Malem Seña sostienen que en su formulación más simple, la teoría del consentimiento adopta la forma de una autorización, mientras que en su versión más compleja adquiere la forma de un contrato. ${ }^{27} \mathrm{Su}$ importancia radica en que constituye un esfuerzo serio para intentar justificar la moralidad del acatamiento a la ley, basándolo únicamente en la voluntad del agente, en su propio discernimiento, es decir, subrayando la libertad de los individuos en la elección de sus propias decisiones morales. La teoria del consentimiento además cumple con una doble función: la de generar obligaciones políticas en el ciudadano y la de legitimar al gobierno que ha sido elegido con el consentimiento de los gobernados. Malem precisa sus presupuestos:

El primero de ellos, es que el hombre que ha nacido libre, permanece libre en un Estado que él mismo ha contribuido a forjar mediante actos voluntarios, y que sólo por medio de este tipo de actos una persona puede enajenar parte de sus derechos a favor del Estado; institución ésta que rige en beneficio de todos y que constituye la mayor y mejor garantía para el mantenimiento y desarrollo de todas las potencias de sus ciudadanos. ${ }^{28}$

26 Dworkin, Ronald, Law's Empire, Harvard University Press, Cambridge, Mass, 1986, pp. 225-275. También véase: Dworkin, Ronald, "Thirty Years On", Harvard Law Review, vol. 115, núm. 6, abril de 2002, pp. 1655-1687.

27 Malem Seña, Jorge, op cit., nota 14, p. 26.

28 Ibidem, p. 28. 
La teoría del consentimiento, al insistir en las vías formales de adopción del acuerdo, ha sido acusada de procedimentalista. Tal es el caso de Peter Singer que centra su estudio $^{29}$ en tres modelos de asociación, dos de los cuales no son democráticos y uno si lo es. Los dos primeros modelos carecen de interés en el estudio de Singer, en razón de que en un sistema no democrático no existen bases morales para obedecer las normas, mandatos y programas, en tanto que no todos los sujetos participan directa o indirectamente en su elaboración, ni se han puesto de acuerdo sobre sus resultados. En cambio, en un sistema democrático, la obediencia al derecho es sostenible, pues se acepta un procedimiento de toma de decisiones que representa un compromiso justo entre las pretensiones concurrentes al poder, en donde aceptar significa participar en el procedimiento de toma de decisiones y acatar sus resultados, y en segundo lugar, y de acuerdo con este modelo democrático, la participación en un procedimiento de toma de decisiones cuando todos participan en él de buena fe, crea la obligación de acepar los resultados del procedimiento.

De esta forma, en una sociedad democrática modelo, hay razones morales muy importantes para obedecer las leyes. Sin embargo, Singer aclara que las razones para obedecer las leyes sólo son aplicables cuando no ha habido infracción alguna de derechos que son esenciales para el funcionamiento de un procedimiento justo. Entre tales derechos se cuentan los derechos democráticos de libertad de expresión, libertad de asociación, derecho a la emisión del voto, entre otros. Singer considera que existen formas de desobediencia limitada que no van contra las razones democráticas para la obediencia, como la que se propone obtener publicidad para un punto de vista que no ha recibido una audiencia justa y la que tiene a conseguir la reconsideración de una decisión. Para Singer, estas formas de desobediencia civil son compatibles con el compromiso justo y son elementos importantes para la estabilidad del sistema. 
¿ES POSIBLE EL ESTADO DE DERECHO...

La obra de Singer aprecia, por tanto, que sólo en un modelo democrático existe la obligación o el deber natural de respeto a obedecer las normas. En los sistemas no democráticos no existen suficientes elementos de participación política ni los derechos están salvaguardados, por lo que no se da el "compromiso justo" al no haber acceso al establecimiento de las reglas del juego ni a sus resultados. La idea de "compromiso justo" es fundamental para comprender la obediencia al derecho en un sistema democrático, en razón de que si todos participan en la elaboración de las normas o establecieron mecanismos adecuados de representación política como las libertades de participación política, entonces es dificil hablar de desobediencia. No obstante, y a pesar de la perfección lógica del modelo, el error de Singer estriba en considerar al "compromiso justo" sólo en cuanto al procedimiento, y no referirlo al valor de las decisiones que son tomadas por los participantes en el compromiso. Es decir, el llamado "compromiso justo" puede ser impecable desde el punto de vista de los mecanismos de participación política, pero las decisiones tomadas por los miembros de la comunidad pueden ser aberrantes y contrarias a valores o derechos como la igualdad, la libertad, el pluralismo, etcétera. De ahí que a Singer le haya faltado incorporar a su idea de "compromiso justo", la de corrección de las decisiones o resultados conforme a derechos humanos.

Singer, pues, no conectó adecuadamente el tema de la obediencia al derecho y desobediencia civil con el de la legitimidad. Y al no hacerlo, al no unir procedimiento justo con resultados justos, derivó en un procedimentalismo formalista que puede justificar el acatamiento a normas, mandatos e instituciones aberrantes y opuestas a los derechos humanos. No basta por tanto un procedimiento democrático para obedecer a las normas, es necesario que ese procedimiento venga acompañado por garantías de respeto a los derechos humanos, mecanismos de control de los procedimientos y de los resultados, fórmulas de rendición de cuentas efectivas, etcétera. 
El trabajo de Singer representa sólo un punto de vista entre variadas orientaciones de las teorias del consentimiento. Existen casos extremos dentro de este arco. Por ejemplo, el del consentimiento expreso que exige el consentimiento manifiesto de todos los ciudadanos de un Estado para cada una de las decisiones de la autoridad. Otra vertiente, la del consentimiento tácito, precisa que el consentimiento se otorgue mediante el silencio o la inactividad y nunca en forma abierta o manifiesta; que la posición en la que se encuentre el que consiente debe ser absolutamente clara respecto del acto de consentir, de lo apropiado de la situación para hacerlo y de la voluntad para realizar el mismo; que exista un periodo de tiempo razonable para posibles alternativas al consentir; que el punto sobre el cual se consiente debe estar perfectamente establecido y debe ser expuesto de manera inequívoca al posible "consentidor"; el disenso ha de poder manifestarse fácilmente tanto en lo referente a las oportunidades como a los medios de realizarlo; y que las consecuencias para quien disiente no deben ser graves ni deben ir en detrimento del posible disidente por el mero hecho de serlo. ${ }^{30}$ Otra posición importante, dentro de la teoría del consentimiento, es la del consentimiento de la mayoría, nacida de la imposibilidad práctica de que todos los individuos consientan de manera expresa o tácita, y de la obvia imposibilidad de la unanimidad y, desde luego, esta teoría es criticada por la situación en la que quedan las minorias respecto a la obediencia de normas, programas o politicas que no se comparten.

De lo expuesto, es obvio que una teoría exclusivamente basada en el consentimiento procedimentalista es insuficiente. No se desconoce la importancia del consentimiento democrático pero no basta para explicar la obediencia a las normas y a la autoridad. A las teorias del consentimiento les faltan las razones finalistas, los objetivos de las normas, los elementos que miden la calidad de una democracia 
¿ES POSIBLE EL ESTADO DE DERECHO...

como el logro o no de la igualdad, la libertad, la rendición de cuentas.

\section{La tesis de Joseph Raz}

En sus trabajos Raz ha aducido que no existe una obligación moral de obedecer el derecho, ni siquiera prima facie. A partir de su concepción de la autoridad basada en las tres tesis: de la dependencia, de la justificación normal y de la exclusividad, Raz supone que todo sistema jurídico vigente en cualquier lugar tiene autoridad de facto, es decir, tiene la pretensión de poseer autoridad legítima, aunque puede no tener legitimidad si le faltan los atributos morales exigidos para investirlo de autoridad legítima. Esa pretensión de autoridad se manifiesta en el hecho que las instituciones jurídicas son denominadas oficialmente como autoridades, en el hecho de que se consideran con derecho a imponer obligaciones a sus gobernados, en su afirmación que los gobernados le deben obediencia y que deben obedecer el derecho de la forma que éste exige ser obedecido, incluso una mala ley debe ser obedecida. ${ }^{31}$ Esto es, la razón de obediencia es principalmente sociológica, la legitimidad se mide por el éxito que tiene la autoridad en ser respaldada. ${ }^{32}$ Sobre la tesis de la incorporación de la moral en el derecho y, en su refutación a Coleman, señala que es muy probable que exista alguna conexión necesaria entre el derecho y la moral, y que todo sistema jurídico tenga algún mérito moral o realice algún bien moral; sin embargo, lo relevante no son las fuentes morales en el derecho, la clave está en que institucionalmente ciertas normas son consideradas derecho. ${ }^{33}$

Raz considera que algunas personas tienen razones morales para obedecer el derecho pero eso no significa una obligación general de obediencia. Propone una cuestión:

31 Raz, Joseph, La ética en el ámbito público, Barcelona, Gedisa, 2001, pp. 227-257.

32 Ibidem, p. 237.

33 Ibidem, pp. 244-249. 
¿cuál debe ser la actitud de un ciudadano escrupuloso hacia las disposiciones jurídicas de una sociedad cuyo sistema es por lo general bueno y justo? ${ }^{34}$ La respuesta es la de respeto por el derecho. El respeto tiene dos componentes: el cognoscitivo y el práctico. La actitud cognoscitiva consiste en el conocimiento sobre el valor moral del derecho y de las inclinaciones y disposiciones tanto afectivas como prácticas apropiadas para ello. Raz estima que tanto el conocimiento como las disposiciones afectivas y prácticas varian según el caso y según la persona de cuya actitud se trate, puede consistir en la creencia de que el derecho es democrático y justo, de que contribuye al progreso social o que protege los derechos de los individuos, etcétera. Por su parte, la actitud práctica de respeto consiste en gran medida, en la inclinación de obedecer el derecho y también, en una variedad de disposiciones afectivas y cognoscitivas, así como otras disposiciones prácticas para ello. Estas disposiciones son tan bien variables, y pueden incluir hostilidad hacia los infractores del derecho, satisfacción cuando éstos son procesados, aprobación del comportamiento jurídico obediente y de las personas que obedecen el derecho, etcétera. ${ }^{35}$ Desde luego que el respeto por el derecho en Raz es un sustituto de la obligación de obedecerlo, al grado que llega a sostener que: "En todo caso, para la persona que respeta el derecho existe una obligación de obedecer. Su respeto es la fuente de esta obligación". 36

La objeción a la tesis del respeto por el derecho descansa en su vaguedad, pues es insuficiente la liga entre el individuo y el sistema jurídico-político. No es suficiente la lealtad y la confianza al sistema para salvaguardarlo, mantenerlo y mucho menos legitimarlo. La actitud del individuo debe ser decidida, profunda, comprometida, para poder reforzar el sistema, y en su caso, legitimarlo con base en razones éticas. Una mera confianza o respeto en el derecho puede ge-

34 Raz, Joseph, La autoridad del derecho, cit., nota 6, p. 309.

35 Ibidem, pp. 310 y 311.

36 Ibidem, p. 320. 
¿ES POSIBLE EL ESTADO DE DERECHO...

nerar abusos por parte del poder al no contar con la participación crítica, comprometida y moral de sus ciudadanos. La obediencia al derecho se traduce en esta hipótesis que comentamos un medio de control al poder. El respeto por el derecho no basta. El ordenamiento jurídico debe superar la conformidad con el sistema y las normas, pues

...intenta ser la vía de llegar a mayores objetivos éticos y se propone otras exigencias más dificiles referentes a su legitimidad y al contenido de las normas, y gana por tanto en "moralidad", es decir, en la garantía de un mayor grado de autonomía, libertad, seguridad e igualdad para los ciudadanos, entonces la respuesta de éstos tiene que estar a la altura de las obligaciones contraídas por parte del Estado. ${ }^{37}$

No obstante, Raz reconoce el valor del Estado de derecho y lo hace con argumentos más que sociológicos, de un tinte marcadamente moral o axiológico. Señala la liga entre el Estado de derecho y una sociedad pluralista en proceso de cambio, destaca dos virtudes del Estado de derecho: la justicia pluralista y la continuidad democrática. Esas virtudes, según Raz, sólo pueden lograrse en un país que tenga una cultura democrática y una cultura de la legalidad, que incluyan una tradición de independencia de los tribunales, la profesión de la abogacía, la policía y la función pública. Se trata de ideales que no pueden asegurarse con la sanción de unas cuantas leyes y no se trata de un ideal libre de toda mancha, pues existen en el Estado de derecho problemas de denegación o acceso efectivo a los tribunales, así como alienación con respecto al derecho. Es escéptico sobre la manera de evitar estas dificultades y arguye que la conciencia de su existencia debe disciplinarnos y hacer lo posible para minimizarlas, y sobre todo ser modestos en nuestro orgullo en cuanto al Estado de derecho. ${ }^{38}$

37 Fernández, Eusebio, La obediencia al derecho, cit., nota 9, p. 125.

38 Raz, Joseph, op. cit., nota 31, p. 404. 


\section{Algunas formulaciones españolas sobre el tema}

No hace mucho tiempo el profesor Felipe González Vicén sostuvo que no hay una obligación ética para obedecer el derecho pero sí una obligación ética para desobedecerlo. ${ }^{39}$ Javier Muguerza ha seguido con algunos matices los pasos del profesor González Vicén, y frente a ellos, profesores como Manuel Atienza, Elías Díaz, Eusebio Fernández, Adela Cortina y Esperanza Guisán, han mantenido argumentos a favor de la existencia de una obligación ética para obedecer el derecho.

\section{Para González Vicén}

...en tanto que orden heterónomo y coactivo el derecho no puede crear obligaciones, porque el concepto de obligación y de un imperativo procedente de una voluntad ajena revestida de coacción son términos contradictorios... Con ello desembocamos en el gran problema de los límites de la obediencia jurídica. Si no hay más obligación que la obligación en sentido ético, el fundamento de la obediencia al derecho basado en el aseguramiento de las relaciones sociales o en otras razones análogas es sólo, por así decirlo, un fundamento presuntivo o condicionado; un fundamento que sólo puede serlo en el pleno sentido de la palabra si el derecho no contradice el mundo autónomo de los imperativos éticos. Si un derecho entra en colisión con la exigencia absoluta de la obligación moral, este derecho carece de vinculatoriedad y debe ser desobedecido... O dicho con otras palabras: mientras que no hay fundamento ético para la obediencia al dere-

39 González Vicén, Felipe, "La obediencia al derecho", Estudios de filosofía del derecho, Tenerife, Facultad de Derecho, Universidad de la Laguna, 1979; del mismo autor "La obediencia al derecho. Una anticrítica", Sistema, núm. 65, 1985, pp. 101-105; Muguerza, Javier, "La obediencia al derecho y el imperativo de la disidencia (una intrusión al debate)", Sistema, núm. 70, 1986, pp. 27-40; Atienza, Manuel, "La filosofia del derecho de Felipe González Vicén", El lenguaje del derecho, homenaje a Genaro R. Carrió, Buenos Aires, Abeledo-Perrot, 1983; Díaz, Elías, De la maldad estatal y la soberanía popular, Madrid, Debate, 1984; Fernández, Eusebio, La obediencia al derecho, cit., nota 9; Cortina, Adela, "La calidad moral del principio ético de la universalización", Sistema, núm. 77, 1987, pp. 111-120; Guisán, Esperanza, "Razones morales para obedecer al derecho", Anales de la cátedra Francisco Suárez, Madrid, núm. 28, 1988, pp. 131 y ss. 
¿ES POSIBLE EL ESTADO DE DERECHO...

cho, sí que hay un fundamento ético absoluto para su desobediencia. Este fundamento está constituido por la conciencia ética individual. ${ }^{40}$

El problema, como puede apreciarse, se genera porque el profesor González Vicén entiende la ética desde el plano de las razones absolutamente autónomas, y el derecho contradice el mundo autónomo de los imperativos morales. "La obligatoriedad ética no se encuentra en los órdenes sociales, sino sólo en la autonomía de la individualidad moral, es decir, en los imperativos de la conciencia". ${ }^{41}$

Javier Muguerza, ${ }^{42}$ al igual que González Vicén, está de acuerdo en el derecho a la desobediencia al derecho pero no a la obligación moral de obedecerlo. Fundamenta la desobediencia en el imperativo kantiano de los fines, basado en su formulación de que "el hombre existe como un fin en sí mismo y no tan sólo como medio", por lo que la autonomía individual no podria ser vulnerada por normas que instrumentalizaran como medios a la persona. La posición de $\mathrm{Mu}-$ guerza repite que los planos éticos existen exclusivamente en la conciencia individual, y que no pueden ser trasladados a los espacios sociales, lo que es a todas luces reduccionista. A este respecto Manuel Atienza ${ }^{43}$ ha señalado que aunque los imperativos éticos tengan su origen en la conciencia individual, pueden referirse a acciones sociales, pues es posible que los mandatos jurídicos coincidan con los imperativos éticos de la conciencia individual, y además, la ética tiene una dimensión social que no puede ser negada. Por otra parte, los imperativos morales precisan de la generalización al tener la pretensión de ser universales.

40 González Vicén, Felipe, "La obediencia al derecho", Estudios de filosofía del derecho, cit., nota 39, pp. 386-388.

41 Ibidem, p. 388.

42 Muguerza, Javier, "La obediencia al derecho y el imperativo de la disidencia (Una intrusión en un debate)", Sistema, cit., nota 39, pp. 27-40.

43 Atienza, Manuel, "La filosofia del derecho de Felipe González Vicén", El lenguaje del derecho, homenaje a Genaro R. Carrió, cit., nota 39, pp. 43 y ss. 
El profesor Elías Díaz ${ }^{44}$ está a favor de la existencia de un fundamento ético tanto para la obediencia como para la desobediencia al derecho, tesis que hace derivar de la concordancia o discrepancia de fondo entre normas jurídicas y normas éticas. Se puede, desde un punto de vista, obedecer a unas normas y desobedecer a otras. En ambos casos, la conciencia individual es el árbitro para resolver las cuestiones, y para fundar o no la obediencia o la desobediencia. Eusebio Fernández, previas matizaciones a la obra de Elías Díaz, se muestra de acuerdo con la obediencia al derecho basada en razones morales. Distingue dos tipos de obligación moral:

La obligación moral en su sentido estricto o fuerte, que sería la basada en los imperativos de la conciencia individual y autónoma, y la obligación moral en su sentido secundario o derivado, que sería la obligación moral que es fruto de la aceptación por parte de la conciencia individual de una norma de origen heterónomo pero que desde el momento de su aceptación se convierte en norma moral. ${ }^{45}$

Esta distinción le permite a Eusebio Fernández defender la idea de que existe una obligación moral de obedecer al derecho justo derivada del imperativo moral de ser justos.

Adela Cortina, ${ }^{46}$ parte de la perspectiva de Habermas y K. O. Apel, y afirma que existe un deber ético indirecto de obediencia al derecho. Recuerda que desde la perspectiva habermasiana, la relación que existe entre la moral y el derecho es de complementación - no identificación-, y que esta necesidad de complementación cuando consiste en la urgencia de absorber desde el derecho coactivo las irregularidades a las que está sometido el procedimiento moral, puede fundamentarse moralmente, y que precisa-

44 Díaz, Elías, De la maldad estatal y la soberanía popular, cit., nota 39, pp. 79 y ss.

45 Fernández, Eusebio, La obediencia al derecho, cit., nota 9, p. 109.

46 Cortina, Adela, "La calidad moral del principio ético de la universalización", Sistema, cit., nota 39, pp. 110-120; id., "Límites y virtualidades del procedimiento moral y jurídico", Anales de la cátedra Francisco Suárez, núm. 28, 1988, pp. 51 y ss. 
¿ES POSIBLE EL ESTADO DE DERECHO...

mente por razones morales es preciso apelar al derecho que cuenta con la facultad coactiva. La remisión a Apel también es importante, pues desde una ética responsable exigir el universal cumplimiento de normas sin tener certeza de que van a ser universalmente seguidas conduce al utopismo o, lo que es idéntico, a la irresponsabilidad. Por tanto concluye que si bien puede haber razones morales para desobedecer al derecho, también pude haber razones para obedecerlo, dado que, desde una ética de la responsabilidad, desde una ética que contempla la vertiente universalizable del fenómeno moral - es decir, la deontológica-, es un deber moral potenciar un derecho válido, incluso mediante la obediencia.

Esperanza Guisán 47 hace una crítica a la concepción restrictiva que sobre la ética tiene el profesor González Vicén. Durante su exposición defiende la tesis de que el derecho debe estar siempre subordinado a la ética para ser legitimado. Tal legitimación o justificación moral no depende del consenso mayoritario sin más y tampoco se funda en una "autoridad" racional que se superponga a las voces y demandas humanas. Crítica que sea la conciencia de cada individuo la que determine en qué casos debe o no respetar, obedecer o desobedecer el derecho, pues se caería en el intuicionismo ético. Para ella, las "conciencias particulares" no son tales, habida cuenta de que las "conciencias", como la psicología y la sociología prueban contundentemente, no son instancias que operen autónomamente sino que los valores sociales vigentes son incorporados al esquema de nuestra propia conciencia como algo indiscutiblemente valioso. Admite sólo a la conciencia crítica como instancia legitimadora del derecho, siempre que se trate de una conciencia crítica formada discursivamente como Habermas propugna, esto es, como requisito formal, y que tenga como contenido aquello que construye el minimo derecho natural que el derecho positivo posee según Hart. La obediencia al

47 Guisán, Esperanza, "Razones morales para obedecer al derecho", Anales de la cátedra Francisco Suárez, cit., nota 39, pp. 133 y ss. 
derecho se justifica en la medida en que las normas jurídicas ayudan al individuo a realizar las metas que se ha propuesto, es decir, cuando procede a formar planes de vida de forma libre, ilustrada, y desde una perspectiva imparcial, y cuando ese auxilio se lleva a cabo con el menor costo en sufrimientos posible.

\section{La obediencia al derecho desde una visión contractualista ${ }^{48}$}

Algunas corrientes del contractualismo sostienen que existe una obligación, aunque sea prima facie, para obedecer las normas jurídicas. La obligación de obediencia no es ilimitada, y existe siempre y cuando se reúnan dos exigencias: 1) Que el derecho a obedecer sea producto de un procedimiento democrático abierto, transparente, plural, público, con participación de los destinatarios de la norma, y 2) que el resultado del procedimiento sea justo, esto es, que respete, preserve y garantice los derechos humanos. La primera exigencia es propia de las teorias procedimentalistas como la de Singer o William N. Nelson. ${ }^{49}$ Teorías que definen a la democracia como un sistema para tomar decisiones gubernamentales. Nelson en particular, alude a las por él llamadas teorías de resultados, criticándolas porque desde su punto de vista comprenden concepciones predeterminadas sobre los derechos humanos. Nelson ve la democracia sólo desde el punto de vista de la democracia representativa. Los puntos deleznables de una elaboración como la de Nelson se

48 Este desarrollo se realizó en Cárdenas, Jaime, El contractualismo y su proyección jurídico-política, Universidad Autónoma de Querétaro, 1991. Es un estudio sobre el contractualismo de la ilustración y el neocontractualismo de Rawls, Nozick y Buchanan. En otras tradiciones como el comunitarismo la obediencia al derecho será consecuencia de las virtudes de la comunidad y de la identificación de las personas con ellas. Véase Macintyre, Alisdair, Alter Virtud, University of Notre Dame Press, 1981; Toulmin, Stephen, "The recovery of practical philosophy", Avalon Lecture, Northwestern University, 1987; Sandel, Michael, Liberalism and the Limits of Justice, Cambridge University Press, 1982; Taylor, Charles, Hegel and Modern Society, Cambridge University Press, 1979, etcetera.

49 Nelson, William, La justificación de la democracia, Barcelona, Ariel, 1986. 
¿ES POSIBLE EL ESTADO DE DERECHO...

pueden sintetizar en dos: 1) su reduccionismo, pues no es dable defender un sistema de justicia procesal puro y limitar el ámbito de la democracia; 2) su inflexibilidad para con los contenidos del procedimiento democrático. Sobre el primer punto parece que Nelson teme las formas de democracia directa o semidirecta sin una base sólida. Desde Rousseau a Macpherson se han considerado que las formas participativas se apoyan en la dignidad del hombre, es decir, en la autonomía moral, y que éste es un apoyo sólido para considerarlas formas éticamente correctas. Como se ha dicho en otros apartados de este trabajo, la democracia directa hoy en día, por sí misma, es imposible, pero bien puede ser un correctivo a la democracia representativa y constituye un mecanismo de gran utilidad para promover al interior de partidos y de otros grupos la democracia interna. La democracia representativa necesita de controles interelectorales para ser de mejor calidad y éstos pueden ser proporcionados con métodos como la revocación de mandato, la iniciativa legislativa popular, el referéndum, etcétera. El sistema de democracia representativo puro adolece de apertura, publicidad, transparencia, participación y deliberación.

En cuanto a considerar a la democracia sólo como procedimiento, es obvio que en éste, cuanto más amplio y ecuánime haya sido el debate previo a una decisión, cuánto más se haya procurado honestamente adoptar un punto de vista imparcial y racional, cuanta más gente haya concurrido libremente en la decisión, cuanto más posibilidades haya de revisarla, tanto más sólida será la presunción de legitimidad de esa decisión. Sin embargo, y como el mismo Nelson reconoce al admitir la desobediencia civil, siempre queda la duda de si la decisión producto del procedimiento es justa. Por tanto, la democracia, que es el ámbito exclusivo en donde puede existir una obligación moral para obedecer el derecho, debe justificarse en cuanto que tiende a conformar procedimientos imparciales y transparentes de participación politica sobre otros sistemas que lo impiden, pero también debe justificarse en cuanto que sus resultados (siem- 
pre en posibilidad de ser revisados) permite el libre despliegue de los planes y proyectos individuales de vida, dando así cumplimiento al imperativo categórico kantiano de no ver a las personas como medios sino como fines. Lo anterior nos lleva a la conclusión de que la democracia no es un sistema de justicia procesal puro, eso podria en todo caso darse en condiciones contra fácticas, sino un sistema procesal imperfecto (las decisiones pueden ser injustas), y por consiguiente, el procedimiento no debe verse en exclusiva sino atender también a los resultados, y Nelson, al igual que otros procedimentalistas, parece olvidarse de ellos. La democracia se justifica porque cuenta con procedimientos abiertos, públicos, transparentes, de respeto a las minorías, etcétera y, además permite la revisión de los resultados.

La anterior relación entre procedimiento y democracia, es la misma relación que Carlos Santiago $\mathrm{Nino}^{50}$ ha atribuido al desarrollo del discurso moral. Nino propone al respecto la hipótesis de que la democracia es un sucedáneo del discurso moral, esto es, se trata de unir la democracia con la discusión pública de cuestiones de moralidad social o del ejercicio del discurso moral aplicado a los asuntos públicos. Existe de esa manera una conexión intrínseca entre democracia y moralidad. Los partidos, por ejemplo, dentro de un sistema democrático, expresarian las diferencias ideológicas relevantes sobre los principios de moralidad válidos. La elección de unos u otros principios es el objetivo del proceso de toma de decisiones democrático, que propicia a su vez la moralización de la política, al atenuar el choque de intereses con la necesidad o exigencia de ofrecer justificaciones morales para favorecer un punto de vista determinado. Según Nino las condiciones que subyacen al proceso discursivo y deliberativo son: que todas las partes interesadas participen en la discusión y en la decisión, que participen de una base razonable de igualdad y sin ninguna coerción,

50 Nino, Carlos Santiago, La Constitución de la democracia deliberativa, Barcelona, Gedisa, 1997, pp. 21 y ss. 
¿ES POSIBLE EL ESTADO DE DERECHO...

que puedan expresar sus intereses y justificarlos con argumentos genuinos, que el grupo tenga una dimensión apropiada que maximice la probabilidad de un resultado correcto, que no haya ninguna minoria aislada, que la composición de las minorías y mayorías cambie con las distintas materias, etcétera. ${ }^{51}$

Otros autores como Rawls, Habermas o Pettit insisten también en los aspectos deliberativos. Rawls, aunque de manera tibia, dice que los principios de justicia deben satisfacer condiciones formales tales como las de universalidad, generalidad, publicidad y finalidad y, que el rol de la teoría moral es describir nuestra capacidad moral para juzgar las cosas como justas o injustas y dar razones sobre ello; la deliberación así sería parte de un sistema puro de justicia procedimental. ${ }^{52}$ Habermas como sabemos, señala que el discurso práctico está constituido por interacciones comunicativas por medio de las cuales los participantes coordinan sus comportamientos argumentando a favor o en contra de las posiciones esgrimidas y que la moralidad de una norma o una decisión depende de la aceptación no coactiva de los demás. ${ }^{53}$ Pettit dice que:

...el demos o pueblo que se gobierna a sí mismo puede marchar las más de las veces con el piloto automático puesto, permitiendo que la toma de decisiones públicas se realice de acuerdo con procesos rutinarios más o menos inescrutados. Lo que hace gobernarse a sí mismo, lo que le hace democrático, es el hecho de que no está, quieras que no, sometido a esa pauta de toma de decisiones: el hecho de que sea capaz de disputar a voluntad esas decisiones y de que, según el resultado de esa disputa, según queden parados sus intereses

51 Ibidem, p. 180.

52 Rawls, John, "Kantian Constructivism in Moral Theory", Journal of Philosophy, núm. 77, 1980, pp. 515-572.

53 Habermas, Jürgen, "Discourse Ethics: Notes on a Program of Philosophical Justification", Moral Consciousness and Communicative Action, Christian Lenhardt y Shierry Weber Nicholsen (traductores), Cambridge, The MIT Press, 1990, pp. 43-115. 
y sus opiniones relevantes, sea capaz también de obligar a alterarlas. ${ }^{54}$

Como se ha dejado asentado aquí, la primera exigencia para obedecer al derecho desde un punto de vista exclusivamente procedimental o formal no basta, se requiere saber si los resultados del procedimiento promueven, respetan y garantizan los derechos humanos. Esta segunda exigencia tiene su origen en tres principios fundamentales: la inviolabilidad, la autonomía y la dignidad de la persona. 55 El primer principio:

...proscribe la imposición de cargas y sacrificios no compensables a ciertos individuos (sin contar con su consentimiento efectivo) sobre la base de que ello redunda en beneficio - incluso en un grado comparablemente mayor al perjuicio causado a aquellos individuos- de la mayoría de la población (o del Estado, una raza superior, una cierta clase social, etcétera). 56

Es evidente la vinculación de este principio con los imperativos categóricos kantianos, 57 y su rechazo a las concepciones utilitaristas $\mathrm{u}$ holistas que ponen a una entidad (el Estado, el pueblo, la colectividad) por encima del individuo. El segundo principio establece la neutralidad del Estado respecto de los planes de vida individuales e ideales de excelencia humana, limitándose a diseñar instituciones y adoptar medidas para facilitar la persecución individual de esos planes de vida y la satisfacción de los ideales de excelencia que cada uno sustenta. Autores como Adela Cortina

54 Pettit, Philip, Republicanismo. Una teoria sobre la libertad y el gobierno, Barcelona-España, Paidós, serie Estado y sociedad, 1999, p. 243.

55 Nino, Carlos Santiago, Ética y derechos humanos, Buenos Aires, Paidós, 1984, pp. 109 y ss.

56 Nino, Carlos Santiago, La fundamentación liberal de los derechos individuales básicos, Barcelona, Ariel, 1983, pp. 418 y 419.

57 Principalmente con el que establece "Actúa de tal modo que nunca trates a la humanidad, sea en tu propia persona o en la de cualquier otro, como un mero medio sino siempre al mismo tiempo como un fin". 
apelan a este principio como el fundamental para legitimar al Estado y la obediencia al derecho. ${ }^{58}$ La importancia de este segundo principio radica en oponerse al enfoque perfeccionista, según el cual es misión del Estado hacer que los individuos acepten y lleven a cabo ciertos ideales de excelencia humana homologados por el mismo Estado. Por otra parte, posibilita un tratamiento adecuado de las politicas de paternalismo estatal, como la obligatoriedad de la educación, las leyes de seguridad social, la prohibición del duelo, etcétera. Este principio se concilia con la excepción de que los propios planes de vida y el desarrollo de la personalidad no pueden perjudicar el mismo derecho de los demás, o los intereses de terceros. Sobre el tercer principio, muchos autores lo señalan 59 como el fundamental y decisivo para justificar los derechos humanos. Expresa

...que las personas deben ser juzgadas y tratadas para ciertos fines, sobre la base exclusiva de sus acciones voluntarias y no según otras propiedades y circunstancias, como su raza, su sexo, sus particularidades físicas y procesos fisiológicos, su pertenencia a cierta clase social, la profesión de ciertas creencias (considerando que éstas no se adquieren y se abandonan voluntariamente), etcétera. 60

Los anteriores principios permiten justificar a los derechos humanos, y al mismo tiempo muestran cómo el individuo está por encima del Estado, y cómo éste debe encargarse de respaldarlos y garantizarlos como función primordial.

58 Cortina, Adela, "La justificación ética del derecho como tarea prioritaria de la filosofia política. Una discusión desde John Rawls", Revista Doxa, núm. 2, 1985, pp. 129-144; Cortina, Adela, Ética minima, Tecnos, 1986, pp. 181 y ss.; Nino, Carlos Santiago, "Autonomía y necesidades básicas", Doxa, Alicante, núm. 7, 1990, pp. 21-34.

59 Spaemann, Robert, "Sobre el concepto de dignidad humana", Revista Persona y Derecho, Pamplona, núm. 19, 1988, pp. 13 y ss.; Hierro, Liborio, “¿Derechos humanos o necesidades humanas? Problemas de un concepto", Revista Sistema, Madrid, núm. 46, 1982, pp. 45 y ss.; y, Laporta, Francisco, "Sobre el concepto de derechos humanos”, Revista Doxa, Alicante, núm. 4, 1987, pp. 23 y ss.

60 Nino, Carlos Santiago, Introducción al análisis del derecho, Buenos Aires, Astrea, 1980, pp. 421 y 422. 
Estos principios dan origen a derechos humanos que asumen dos componentes: uno negativo y otro positivo. Por ejemplo, el derecho a la vida y a la integridad corporal no sólo debe verse como la ausencia de actos que vulneren la vida y la integridad corporal, sino también como el derecho a contar con los servicios y beneficios de la medicina preventiva y curativa, con el derecho al albergue, al abrigo, al descanso, etcétera, y lo mismo respecto a otros derechos básicos como el de la libertad de expresión.

La justificación de la obediencia al derecho de la visión contractualista es doble. La exigencia de un procedimiento democrático, abierto, transparente, público, deliberativo, etcétera, puede fundamentarse en la necesidad del consentimiento y de la participación igualitaria de los destinatarios de la norma para que ésta les sea aplicable. De no cumplirse el elemento del consentimiento, de la participación, de la deliberación, etcétera, es difícil sostener la obligación a una norma totalmente ajena a nosotros e impuesta sobre nuestros derechos e intereses. En cuanto a la exigencia de los derechos humanos, un orden jurídico que no los garantiza y no los considera básicos para el sostenimiento del Estado, es un orden holista que se ha colocado por encima de ellos, y que a nombre de cualquier motivo o razón puede realizar las más descabelladas acciones y cometer los crímenes más atroces. El individuo es y seguirá siendo la causa de las instituciones. Sus derechos fundamentales como en el caso del procedimiento no deben ser producto de una voluntad individual por más esclarecida que ésta sea, deben ser producto de la justificación moral, de razones más allá de cualquier moral positiva, de razones fundadas en el consenso racional y libre de las personas, en donde los participantes tengan derechos a la participación equitativa en el procedimiento. Por eso, los principios de justicia de Rawls, a pesar de las críticas que se han vertido, son un buen ejemplo para la construcción moral y definición de derechos humanos sobre los que debe guiarse el funcionamiento y actuación de las instituciones. 
¿ES POSIBLE EL ESTADO DE DERECHO...

Estamos obligados moralmente a obedecer - prima facie- aquellas normas jurídicas que cumplen con las dos exigencias apuntadas, pues actuar al margen de ellas, es tanto como adoptar una actitud inmoral. Es inmoral obedecer una norma injusta como el dejar de desobedecerla en idénticas condiciones, en razón de que el ser humano tiene una vocación moral indudable que le impele a obedecer el derecho justo de una sociedad civil democrática, y de desobedecer las normas que no son ajustadas a la moral. ${ }^{61}$

\section{La posición de Ferrajoli sobre la obediencia al derecho}

A Ferrajoli le interesa saber si en el Estado constitucional de derecho existe una obligación moral de obedecer las leyes injustas, y si existe, cuáles son su naturaleza y su medida. ${ }^{62}$ Para Ferrajoli, de la obligación jurídica de obedecer las normas, no se deriva una obligación moral como tampoco se desprende de una norma válida que sea también justa. Si se tratara de hacer esos desprendimientos y derivaciones se incurriría en una falacia ideológica del mismo tipo que la de Bentham y Austin, cuando derivaron la existencia de una obligación jurídica de la de una obligación de hecho. Según Ferrajoli, se debe enfrentar el problema articulándolo en dos "subproblemas": en qué consiste la obligación moral y/o politica de obedecer las leyes, y qué sujetos, en un Estado de derecho, están sometidos a ella. El primer subproblema lo atiende distinguiendo las dos versiones ideológicas de la tesis moral, la que rechaza, según la cual es moralmente obligatorio obedecer las leyes sólo porque son válidas. La primer versión, la extremista, confunde la moral con el derecho, lo que es propio de las doctrinas auto-poyé-

61 Peces Barba, Gregorio, "Desobediencia civil y objeción de conciencia”, Anuario de Derechos Humanos, núm. 5, Madrid, 1988-1989, p. 163.

62 Ferrajoli, Luigi, Derecho y razón. Teoría del garantismo penal, Madrid, Trotta, 1989, p. 921 . Véase también: Ferrajoli, Luigi, Derechos y garantías. La ley del más débil, Madrid, Trotta, 1999; id., Epistemología jurídica y garantismo, México, Fontamara, 2004; id., Los fundamentos de los derechos fundamentales, Madrid, Trotta, 2001; y, id., Razones jurídicas del pacifismo, Madrid, Trotta, 2004. 
ticas del Estado ético, y que es incompatible con el pluralismo y la democracia liberal. La segunda versión moderada, acepta la obligación moral de obedecer las normas jurídicas, siempre y cuando éstas estén en relación con otras normas morales de valor superior. Algunos autores como Passerin d'Entréves y Scarpelli reservan la adhesión u obligación política únicamente a las normas que son parte de los ordenamientos jurídicos liberales y democráticos. Ferrajoli no acepta el punto de vista de Passerin d' Entréves y Scarpelli porque le parece apriorístico. No se puede dar un cheque en blanco a ningún ordenamiento, aunque se diga democrático y liberal, es necesario que esté justificada a posteriori la norma o normas en concreto. Además, más allá de la obligatoriedad jurídica apoyada por la fuerza disuasoria de la sanción, prevalecen siempre -en el plano moralvalores superiores a los del orden, como la libertad, la vida, etcétera. Para Ferrajoli, las únicas normas para las que parecería relevante la obligación moral de obediencia, desde el punto de vista del valor orden, son las que prescriben comportamientos escasamente relevantes o simplemente indiferentes en el plano moral.

Por consiguiente, dice Ferrajoli, ${ }^{63}$ la obligación política o es incondicionada o no es propiamente una obligación, y por lo demás, en una concepción hétero-poyética del derecho, éste será moral y políticamente aceptable sólo si es condicionado, es decir, meramente potestativo y, en consecuencia, deónticamente inconsistente, es decir, inexistente; mientras que, si es incondicionado y, por ende, deónticamente consistente, será moral y políticamente inaceptable. Ferrajoli, no obstante, hace una distinción cuando resuelve el segundo subproblema, y así dice que para los jueces y funcionarios, la obligación política de observar las leyes, al identificarse con la de aplicarlas, parecería incondicionada y enteramente formal y, es una cuestión de conciencia de los jueces y funcionarios elegir entre la personificación de tales

63 Ferrajoli, Luigi, Derecho y razón. Teoria del garantismo penal, cit., nota 62, p. 924. 
¿ES POSIBLE EL ESTADO DE DERECHO...

funciones de poder y aceptar hacerlo en un ordenamiento democrático y liberal o en uno totalitario; pero, una vez realizada esta opción, aplicar o no aplicar las leyes, deja de ser una cuestión de conciencia, y así por ejemplo, los jueces penales no son libres de orientarse en las decisiones según sus personales convicciones morales, sino que, por el contrario, deben someterse a las leyes aun cuando pudieran hallarse en contraste con tales convicciones. Pero aclara, la obligación jurídica, antes aún que política, vale para los jueces sólo en relación con las leyes válidas además de vigentes: es decir, únicamente respecto de los parámetros constitucionales conforme a los cuales se encuentra habilitado para valorarlas. ${ }^{64}$ Para Ferrajoli el único auténtico conflicto podría darse cuando los valores morales del juez entran en contradicción con las normas de la Constitución, en ese caso la opción moral del juez es la de dejar de ser juez.

Fuera de los titulares de las poderes delegados para la aplicación de la ley, ningún otro sujeto está obligado moralmente a respetar las leyes, pues una obligación moral incondicionada y extendida a los ciudadanos supone una concepción ética y totalitaria del Estado que excluye la autonomía de la moral y exige de ésta una conformidad en blanco con el derecho positivo. Ferrajoli sostiene a partir de su modelo de justificación externa, que no puede haber una adhesión a priori a un modelo normativo abstracto sino una adhesión a posteriori condicionada a su efectivo funcionamiento concreto. Estima por ello, que el principio normativo de la desobediencia en relación con leyes que contradigan y comprometan los fundamentos de legitimación interna y externa del ordenamiento sí es una norma moral en la concepción hetéro-poyética del Estado de derecho. ${ }^{65}$ Existiría así un deber moral de desobediencia cuando las leyes entran en conflicto radical con los valores universales y fundamentales sancionados en la Constitución,

64 Ibidem, p. 926.

65 Ibidem, p. 929. 
tal como lo han reconocido documentos jurídicos como el artículo 3o. de la Declaración de Derechos del Buen Pueblo de Virginia, que establece: "la mayoria de la comunidad tiene el derecho indiscutible, inalienable e irrevocable de reformarlo, alterarlo o abolirlo de la manera que juzgue más conveniente al bien público"; y el artículo 29 de la Constitución francesa de 1793 que establecia: "En todo gobierno libre, los hombres deben tener un medio legal para resistir la opresión, y, cuando este medio sea impotente, la insurrección es el más santo de los deberes". Por tanto, Ferrajoli sostiene que no hay un deber moral de obediencia a las normas por parte de los ciudadanos, pero si un derecho o una libertad de desobediencia cuando las normas son injustas de acuerdo a la conciencia moral de cada ciudadano.

Coincidimos con el punto de vista de Ferrajoli de que no existe una obligación incondicionada, apriorística, de obedecer moralmente un ordenamiento jurídico o un aparato institucional, aunque se diga democrático y ajustado al Estado de derecho. También mostramos nuestro acuerdo con el deber moral o libertad de desobedecer normas injustas e inaceptables desde el punto de vista de los fines democráticos y constitucionales del Estado. No obstante, consideramos que sí existe una obligación prima facie de obediencia cuando después de juzgar a las normas jurídicas en sus consecuencias o a posteriori, encontramos en ellas, que tuvieron un origen democrático y que fueron consecuentes con los derechos fundamentales de las personas. Si encontramos esos elementos a posteriori, no vemos porque no pueda reconocerse que existe una base moral para la obediencia de esas normas aunque sea prima facie. En cuanto a la obediencia moral hacia las normas por parte de funcionarios y jueces, podríamos decir, que ésta es de mayor nivel y exigencia que la de los ciudadanos, su adhesión al sistema normativo es más fuerte, y en ellos de manera clara, existe un punto de vista interno hacia el ordenamiento. 
¿ES POSIBLE EL ESTADO DE DERECHO...

\section{NUESTRA POSICIÓN}

De las teorias expuestas nuestra conclusión es que existe una obligación - prima facie de obedecer el derecho, cuando éste es producto de procedimientos democráticos, no sólo representativos, sino participativos, deliberativos, públicos, transparentes, con rendición de cuentas del gobernante al gobernado, con controles sociales efectivos a la función pública, etcétera, y cuando el derecho a obedecer garantiza y respeta los derechos humanos, tanto los de libertad o derechos negativos como los de igualdad o derechos económicos sociales y culturales. Además de estas razones morales para obedecer el derecho, desde luego que existen las jurídicas, que como ya hemos mencionado son tautológicas porque remiten al propio sistema jurídico para fundamentar el deber de obediencia, y las prudenciales o "interesadas" que también son importantes porque se basan en la combinación de premios y castigos que el derecho provee. Sin embargo, ni las razones jurídicas ni las prudenciales tienen el fondo de las razones morales. Al derecho debe obedecérsele, no sólo porque la norma prevé una sanción por su no acatamiento, o porque puede resultar beneficioso para el desarrollo personal, sino porque estamos convencidos de su corrección, de su justeza, porque proviene de procedimientos democráticos y tiene como fin claro e indubitable la garantía de los derechos humanos. Cuando el ciudadano tiene esa convicción profunda el derecho es obedecido, acatado. Es verdad que esta situación sólo puede darse en condiciones ideales, pero en términos kantianos podriamos decir que constituye un principio o una idea regulativa. En el terreno de los hechos y, aunque el nivel de obediencia al derecho de los funcionarios y jueces sea superior al de los ciudadanos, es totalmente posible y ético pretender una especie de "punto de vista interno" para los ciudadanos. Ello es posible cuando éstos se sienten plena- 
mente identificados con su sistema normativo porque lo estiman valioso y respeta su autonomía personal. ${ }^{66}$

La obligación de obedecer al derecho es siempre una obligación prima facie, condicionada, nunca definitiva, a posteriori, pues el ciudadano y la sociedad en su conjunto siempre tienen el inalienable derecho de mostrar su desacuerdo con las normas y de desobedecerlas ${ }^{67}$ cuando éstas no provienen de procedimientos democráticos o no respetan debidamente los derechos humanos. La adhesión al sistema normativo no puede ser incondicionada ni absoluta porque se pondrían en duda los principios de inviolabilidad y autonomía de las personas, se vulneraría la consideración de que cada sujeto, cada persona, es un ente con libertad que no ha cedido ni un ápice su dignidad. Es por tanto la obligación de obediencia, una obligación que se ejerce desde la crítica, la reflexión individual o colectiva de los ciudadanos, que debe desarrollarse de preferencia desde la deliberación de los asuntos públicos, incluyendo normas e instituciones. 68

66 En la encuesta sobre la cultura de la Constitución en México, se encontraron respuestas de este tipo: un $45.9 \%$ de los encuestados opinó que se pueden desobedecer las leyes si le parecen injustas; un $45.1 \%$ de los encuestados afirmó que cumple y obedece las leyes pues nos beneficia a todos; y, un 25\% de los encuestados considera que el respeto y la obediencia a las leyes se deben al seguimiento de un principio moral. Véase: Concha Cantú, Hugo A. et al., Cultura de la Constitución en México. Una encuesta nacional de actitudes, percepciones y valores, México, Tribunal Electoral del Poder Judicial de la Federación-Comisión Federal de Mejora Regulatoria-UNAM, Instituto de Investigaciones Jurídicas, 2004, pp. 22-27. En Argentina en una encuesta similar sobre la cultura constitucional, los argentinos respondieron de la siguiente manera: el 44\% de los encuestados respondió que respeta la ley por ser un deber moral, el 37\% porque ello beneficia a todos, el $9 \%$ para no perjudicar a la familia y amigos, el $8 \%$ para evitar castigos y el $1 \%$ para no ser criticado por los demás. El $41 \%$ admitió la posibilidad de desobedecer la ley en determinados momentos. Véase Hernández, Antonio María et al., Encuesta de cultura constitucional. Argentina: una sociedad anómica, México, Asociación Argentina de Derecho Constitucional-IDEA Internacional-UNAM, Instituto de Investigaciones Jurídicas, 2005, pp. 125 y ss.

67 Rawls, John, Teoria de la justicia, cit., nota 15, p. 140 y Habermas, Jürgen, Conciencia moral y acción comunicativa, ediciones Península, 1985, pp. 110 y ss.

68 Nino, Carlos Santiago, La Constitución de la democracia deliberativa, Barcelona, Gedisa, 1997. Nino, Carlos Santiago, Un pais al margen de la ley. Estudio de la anomia como componente del subdesarrollo argentino, Buenos Aires, Emecé, 1992. 
¿ES POSIBLE EL ESTADO DE DERECHO...

Esta obediencia condicionada y crítica al derecho depende de la existencia o no de procedimientos democráticos. En un sistema donde las normas y las instituciones provienen de condiciones no democráticas, 69 carece de sentido hablar de una obligación moral de obedecer el derecho porque el sujeto no es libre, su autonomía, su inviolabilidad están asfixiadas. El derecho en esos sistemas se impone por la fuerza o la manipulación. La obligación de obediencia al derecho tiene bases en la democracia porque ahí las personas ejercen su libertad, su crítica, su voluntad de consenso o de disenso. Por estas razones, la democracia debe ser ampliada, perfeccionada, y su calidad debe ser promovida. Una democracia representativa, en donde la separación entre el gobernante y el gobernado es abismal y no existen controles efectivos para la rendición de cuentas ni horizontales ni sociales, poco se puede sostener una obligación moral de obediencia al derecho. Bien podriamos establecer una ecuación como la siguiente: a mayor nivel y profundidad de la democracia mayor es la obligación moral de obediencia al derecho. Si queremos que los ciudadanos se sientan obligados por su sistema normativo perfeccionemos la democracia, habrá mayores exigencias para ellos. Con los niveles actuales de democracia no se podrá pedir una obligación en un sentido fuerte. A este respecto conviene recordar a Giovanni Sartori cuando dice "lo que la democracia es, no puede estar separado de lo que la democracia debe ser". 70

También el tipo de Estado de derecho, su conformación y características tienen su parte en esta tarea. Un Estado de derecho de pura legalidad sin un referente fuerte a la Constitución y a mecanismos universales y ciudadanos de control de constitucionalidad o, sin efectiva división de poderes, sin un poder judicial independiente, o con una inexistente admi-

69 Linz, Juan J., "Totalitarian and Authoritarian Regimes", en Greenstein, Fred I. y Polsby, Nelson W. (eds.), Handbook of Political Science, Macropolitical Theory, Massachusetts, Addison-Wesley Publishing Company, vol. 3, 1975.

70 Sartori, Giovanni, Democratic Theory, Detroit, Wayne State University Press, 1962, pp. 4 y 5. 
nistración pública profesional, no genera condiciones para una obligación moral de obediencia al derecho. Cuando el ciudadano sabe que cualquier reclamo puede ser planteado ante un Poder Judicial independiente o que existe una administración civil de carrera que le brinda apoyo y protección, que la Constitución es algo más que un documento político y que constituye una norma directamente esgrimible por él ante los tribunales y que cuenta con amplios medios de defensa a su alcance para proteger sus derechos y la constitucionalidad de las decisiones de las autoridades, existen las bases para poder hablar de una obligación moral de obediencia al derecho. Cuando el Estado de derecho es distante del ciudadano, y no le brinda protección, cuando se carece de vías efectivas para la exigencia de rendición de cuentas, cómo poder sostener que hay una obligación moral de adhesión al sistema normativo. Igual que en el caso de la democracia, si queremos plantear el asunto en términos de una obligación moral de obediencia al derecho, luchemos por perfeccionar el Estado de derecho, hagamos que sea efectivo el control de constitucionalidad, la rendición de cuentas, la división de poderes, etcétera. ${ }^{71}$

71 No cualquier sistema normativo da lo mismo ni tampoco cualquier sistema constitucional es igual. Nino nos recuerda diferentes niveles de desarrollo conceptual del constitucionalismo. Entre ellas menciona: “i) la concepción menos robusta quizá se encuentre asociada a la idea de rule of law, que implica la preservación de algunas reglas jurídicas fundamentales que limitan en cierta medida lo que un órgano particular de gobierno, democrático o no, puede hacer; ii) un concepto un poco más robusto sería más específico respecto del modo en que el gobierno se encuentra limitado por normas jurídicas, requiriendo generalmente de una constitución, aunque no necesariamente materializada en un documento escrito. Cualquiera sea su contenido, esta constitución está protegida desde el momento en que su reforma o derogación exigen procesos más complejos que el requerido para modificar la legislación ordinaria, y se considera suprema respecto de esas normas; iii) un concepto aun más robusto de constitucionalismo contiene restricciones formales que la constitución impone a las leyes sujetas a su supremacía, requiriendo que éstas sean, por ejemplo, generales, precisas, públicas, no retroactivas, estables y que se apliquen imparcialmente sin distinción alguna que la misma ley no haga; iv) podríamos robustecer aun más el concepto si le agregamos la idea de separación de poderes, con especial énfasis en la independencia del poder judicial de los órganos legislativos; $v$ ) una dimensión fundamental se le agrega al concepto de constitucionalismo cuando la constitución reconoce derechos individuales que no pueden ser coartados por ningún órgano del Estado; vi) cuando se 
En el caso de los derechos humanos, de libertad y de igualdad, y de las siguientes generaciones, debemos también decir que una obligación de obediencia moral al derecho es exigible sólo en aquellos casos en donde los derechos humanos son efectivamente garantizados. Si el sistema normativo abandona a los derechos humanos no hay ninguna obligación moral de acatarlo. Sólo existe esta obligación ahí donde las normas tienen un contenido y una orientación compatible con los derechos humanos. La visión garantista de Ferrajoli ${ }^{2}$ a este respecto es explícita con lo que aquí se dice. Sólo desde una visión de los derechos humanos en donde éstos cuentan con garantías y mecanismos efectivos de protección podemos referirnos a una obligación moral de obediencia al derecho, en los demás casos, es como si predicáramos la obligación moral de obedecer el derecho en la Alemania nazi, en la Italia fascista o en la Sudáfrica del apartheid.

¿Cómo generar los hábitos de obediencia al derecho? Por un lado, como aquí se ha señalado, es necesario perfeccionar la democracia, el Estado de derecho, orientar las normas hacia una visión garantista ${ }^{73}$ con la más amplia protección a los derechos humanos, pero por otro, también se requiere ir construyendo una ciudadanía más informada, reflexiva y crítica con sus instituciones y normas. Este últi-

agrega el control judicial de constitucionalidad, el constitucionalismo se hace aún más robusto ya que la justicia independiente se convierte en la única institución capaz de proteger esos derechos y cuenta con el poder de anular la legislación que los amenaza; vii) el concepto se amplia enormemente cuando se agrega la democracia a los requerimientos mencionados, para juzgar el origen de algunas instituciones del gobierno; viii) por último, la robustez del concepto de constitucionalismo depende del modelo particular de democracia que se tome y sus instituciones específicas, tales como la representación, la democracia directa, la necesidad de contar con un cuerpo legislativo colectivo y elegido popularmente, o con un órgano unipersonal, también popularmente electo, pero que reúna funciones legislativas y ejecutivas". Nino, Carlos Santiago, La Constitución de la democracia deliberativa, cit., nota 50, pp. 16 y 17.

72 Ferrajoli, Luigi, Derecho y razón. Teoría del garantismo penal, Madrid, Trotta, 1997, pp. 851 y ss.

73 Carbonell, Miguel y Salazar, Pedro, Garantismo. Estudios sobre el pensamieto juridico de Luigi Ferrajoli, Madrid, Trotta-UNAM, Instituto de Investigaciones Jurídicas, 2005. 
mo aspecto, exige que exista una convicción fuerte y firme para promover el Estado de derecho y combatir la corrupción, un compromiso sin ambages. En casi ningún país del mundo ha existido una politica consistente de parte del gobierno o de la sociedad para insistir en la importancia del Estado de derecho y para enfrentar la corrupción. Por el lado de la educación en contra de la corrupción, habría que mencionar que existen al menos dos dimensiones: una de mera instrucción, que hace referencia a la enseñanza técnica y, la otra, que implica una educación cívica, una enseñanza en los valores. En la parte de la instrucción, la educación se relaciona con reglas técnicas, es decir, con los medios para alcanzar el fin deseado, esto es, proporcionarle al ciudadano, la información sobre los mecanismos a su disposición de control institucional y social, mostrarle el impacto negativo de la desobediencia al derecho, de la corrupción en la economía o en las relaciones sociales, indicarle que los actos u omisiones que constituyen corrupción entrañan el rompimiento de normas jurídicas, enseñarle las normas y cuerpos jurídicos que se infringen con la corrupción y la manera de denunciarla, etcétera. Por lo que ve a la educación cívica, el ciudadano debe ser educado en los valores morales, sobre todo, en aquellos temas que constituyen restricciones al autointerés y que favorecen el autodominio; el ciudadano debe saber que las instituciones y normas jurídicas no expresan exclusivamente relaciones de poder o de dominio, sino que deben estar orientadas hacia el desarrollo de fines como el respeto a la autonomía personal, la libertad, la igualdad; que las normas jurídicas y las instituciones en general deben ser producto de procedimientos democráticos con participación ciudadana efectiva, deliberación de los asuntos públicos, publicidad de los procedimientos y de las decisiones, etcétera; se le debe inculcar la importancia de una relación fuerte entre el gobernante y gobernado, y cómo la rendición de cuentas permite esa relación para controlar al poderoso y evitar los desvíos del poder. La finalidad de la educación cívica debe ser el desa- 
¿ES POSIBLE EL ESTADO DE DERECHO...

rrollo de un punto de vista interno del ciudadano hacia las normas, que éste sepa que tiene una obligación de obedecerlas cuando son justas, esto es, que su establecimiento fue el resultado los procedimientos democráticos y, su finalidad es el respeto de los derechos humanos. ${ }^{74}$

Parte de la educación civica debe consistir en mostrar las razones legales, prudenciales y morales para obedecer el derecho y también para desobedecerlo. Insistir que la adhesión al sistema normativo no es gratuita, que depende en buena medida de cómo ha realizado su labor la clase política al momento de emitir y aplicar las normas. En pocas palabras, que la obligación de obedecer las normas es siempre condicionada y crítica, que el ciudadano debe estar en permanente diálogo crítico con las instituciones y con las normas, y que los gobernantes no tienen un cheque en blanco para hacer lo que quieran. La educación cívica debe apartarse de cualquier fetichismo en torno a la ley, expresiones como "se debe obedecer la ley porque es la ley" deben dejase de lado, y sustituirlas por otras como, "es obligado obedecer la ley cuando ésta fue producto de un procedimiento democrático y es justa porque promueve y garantiza derechos humanos".

En cuanto al ciudadano, si las personas comienzan a tener comportamientos honestos, con independencia de las consecuencias para sus intereses será posible prever comportamientos futuros. Estas actitudes no sólo serán morales sino estratégicas, en el sentido que los demás podrán ajustar sus conductas a las conductas de las personas honestas. Como dice Malem, se inicia un proceso de circularidad causal, donde un comportamiento moral genera como respuesta un comportamiento de igual calidad moral, lo que a su vez genera un nuevo comportamiento moral, tales participantes se identificaran mutuamente como agentes morales y tenderán a cooperar entre sí. Este "mercado de la virtud" produce esquemas de cooperación y confianza so-

74 Malem Seña, Jorge, La corrupción. Aspectos éticos, económicos, politicos y jurídicos, Barcelona, Gedisa, 2002, pp. 211 y ss. 
cial, que no sólo refuerzan las virtudes personales sino que tienen consecuencias en los beneficios económicos que las personas reciben. ${ }^{75}$

¿Cómo generar ese mercado de la virtud? A través de la educación cívica de los ciudadanos. En México y de acuerdo a lo previsto en el artículo 41 de la Constitución, corresponde al Instituto Federal Electoral la educación cívica. No obstante, muchas instituciones públicas y privadas tienen a su cargo la educación cívica, ésta es un proceso que se adquiere durante la vida de una persona. Los ciudadanos también recibimos educación cívica a través del comportamiento de la clase política. Si los políticos de un país son virtuosos trasladarán al resto de la población, tal vez no mecánicamente, pero si con el ejemplo, comportamientos morales. Un político educa a los ciudadanos si respeta las normas y no es corrupto, si lucha contra la corrupción, no basta un comportamiento retórico, los ciudadanos toman en cuenta los hechos. Si los ciudadanos observan que sus gobernantes y politicos incumplen con las normas y se corrompen, los mensajes de éstos no tendrán impacto entre la población, en cambio si tendrá relevancia para mal, un comportamiento corrupto del gobernante, pues manda la señal a la sociedad a favor de esas prácticas. Igualmente, es pedagógico que los gobernantes corruptos sean castigados. Nada hace más daño a la democracia que las conductas ilícitas de un mal gobernante queden impunes. De nada sirven las campañas a favor del Estado de derecho en los medios de comunicación, o los esfuerzos educativos, si después no hay sanciones a los politicos que transgreden las normas. En este mismo sentido, es, por ejemplo, terriblemente dañino que los actos jurídicos que se celebran al amparo de la corrupción, se mantengan firmes y no sean anulados jurídicamente. La falta de anulabilidad de los efectos de las acciones corruptas aparece como un claro mensaje de que vale la pena ser corrupto. 
¿ES POSIBLE EL ESTADO DE DERECHO...

Ahora bien, para que exista el "mercado de la virtud", y los gobernantes con su ejemplo manden señales a favor del cumplimiento del derecho y en contra de la corrupción - no siendo corruptos, castigando a los corruptos, y anulando los actos jurídicos que se producen a consecuencia de la corrupción- es necesario contar con una democracia profunda y de calidad y, es preciso, un Estado de derecho con fuertes mecanismos de control al poder, tanto institucionales como sociales. De esta manera, los elementos institucionales se refuerzan y complementan con el comportamiento de los actores politicos y sociales. 